\title{
PERLINDUNGAN HUKUM PEMEGANG SAHAM MINORITAS PERUSAHAAN TERBUKA AKIBAT PUTUSAN PAILIT ${ }^{*}$
}

\author{
Pita Permatasari ${ }^{1}$ \\ Permalink: https://www.academia.edu/9998733
}

\begin{abstract}
Law Protection for Minority Shareholders of Public Companies due to Bankruptcy Verdict. The lack of protection for minority shareholders of public companies due to bankruptcy verdict is an open secret. The principal of openness in Regulation No. X.K.5/Act of Chairman of Indonesian: Capital Market Supervisory Agency and Financial Institution (Bapepam-LK) No. Kep-46/PM/1998 becomes one of guarantee rights for legal protection for these shareholders. Basically, these kinds of shareholders do not have any rights in a company which hold a principal one share one vote. The rights for these shareholders are to lodge obligation on curator action and supervisory judge besides direct claim of their own.
\end{abstract}

Keywords: minority shareholders, public company, bankruptcy

\begin{abstract}
Abstrak: Perlindungan Hukum Pemegang Saham Minoritas Perusahaan Terbuka Akibat Putusan Pailit. Minimnya proteksi terhadap pemegang saham minoritas dalam suatu perusahaan terbuka yang mengalami pailit. Prinsip keterbukaan dalam Peraturan Nomor X.K.5/Keputusan Ketua Bapepam-LK Nomor Kep-46/PM/1998 menjadi salah satu hak yang menjamin perlindungan hukum pemegang saham minoritas perusahaan terbuka akibat putusan pailit, karena pada dasarnya pemegang saham minoritas tidak memiliki hak yang banyak karena dalam perusahaan menganut prinsip one share one vote. Adapun hak-hak yang diperoleh pemegang saham minoritas perusahaan yang mengalami pailit adalah pengajuan keberatan atas tindakan kurator dan hakim pengawas, selain pengajuan gugatan langsung untuk dan atas nama dirinya sendiri.
\end{abstract}

Kata Kunci: Pemegang Saham minoritas, Perusahaan Terbuka, Pailit

* Diterima tanggal naskah diterima: 12 Juli 2014, direvisi: 24 Oktober 2014, disetujui untuk terbit: 15 November 2014.

${ }^{1}$ Legal Staff di PT Kresna Graha Sekurindo Tbk, sekaligus Mahasiswi Pascasarjana Fakultas Hukum Universitas Indonesia. E-mail: pitapermatasari@gmail.com. 


\section{Pendahuluan}

Perusahaan terbuka yang sudah listing di Bursa Efek atau Emiten dapat melakukan penawaran umum untuk memperjualbelikan efek perusahaannya. Jual beli efek dari perusahaan emiten ini dilakukan di Pasar Modal. Saham yang terdapat dalam perusahaan dikeluarkan dalam rangka pendirian perusahaan, pemenuhan modal dasar atau peningkatan modal dasar. Setiap perusahaan selalu mencari modal untuk meningkatkan modal dasar perusahaannya, di pasar modal inilah perusahaan tersebut mencari investor. Dengan adanya investor inilah perusahaan mempunyai beberapa orang pemegang saham, salah satunya pemegang saham minoritas.

Setiap saham yang dikeluarkan oleh perusahaan mempunyai satu hak suara kecuali Anggaran Dasar menentukan lain. Sejalan dengan ketentuan tentang saham yang menyatakan bahwa perusahaan dapat mengeluarkan satu atau lebih klasifikasi saham, maka dimungkinkan untuk diberikan atau tidak hak suara pada saham yang diterbitkan, termasuk dalam hal ini variasi dari hak suara itu sendiri.

Suara kuorum yang dianggap penting untuk mengeluarkan hak suara inilah terlihat jelas peranan dari pemegang saham mayoritas dan pemegang saham minoritas terlebih ketika perusahaan terbuka mengalami pailit yang berakibat delisting ${ }^{2}$ nya emiten dari bursa efek.

Akibat hukum kepailitan dari perusahaan yang mengalami pailit cukup memporak-porandakan saham dari perusahaan tersebut, karena saham yang dimiliki perusahaan tersebut harus dibayarkan utang kepada kreditur dan kemudian investor yang menanamkan modal di perusahaan terbuka atau emiten yang mengalami pailit tersebut. Prinsip resiko berinvestasi yang dimiliki oleh investor adalah jika emiten yang mereka tanami modalnya mengalami pailit dan sahamnya habis untuk membayar utang, maka investor terakhir atau sahamnya yang paling kecil dalam hal ini pemegang saham minoritas tidak akan mendapatkan haknya. Hal ini tentu sangat merugikan pihak investor terlebih secara struktural investor pemegang saham minoritas.

Prinsip keterbukaan ${ }^{3}$ yang seharusnya diberikan emiten kepada investor sesuai dengan Peraturan Nomor X.K.5/ Keputusan Ketua BapepamLK Nomor Kep-46/PM/1998 tentang Keterbukaan Informasi Bagi Emiten atau Perusahaan Publik yang Dimohonkan Pernyataan Pailit. Namun peraturan tersebut belum cukup untuk melindungi investor, hal ini dikarenakan belum adanya pengaturan yang mewajibkan emiten atau perusahaan publik yang telah dinyatakan pailit untuk melaksanakan prinsip keterbukaan. Dengan tidak adanya laporan yang dilakukan oleh emiten atau

${ }^{2}$ Delisting adalah penghapusan pencatatan dari daftar saham di bursa yang dikarenakan tidak memenuhi ketentuan-ketentuan di bursa tersebut.

${ }^{3}$ Menurut Pasal 1 angka 25 Undang-Undang Nomor 8 Tahun 1995 Tentang Pasar modal, Prinsip Keterbukaan adalah pedoman umum yang mensyaratkan Emiten, Perusahaan Publik, dan Pihak lain yang tunduk pada Undang-undang ini untuk menginformasikan kepada masyarakat dalam waktu yang tepat seluruh Informasi Material mengenai usahanya atau efeknya yang dapat berpengaruh terhadap keputusan pemodal terhadap Efek dimaksud dan atau harga Efek tersebut. 
perusahaan publik, investor akan sulit untuk mendapatkan informasi mengenai kondisi yang terjadi pada perusahaan.

\section{Pengertian Saham}

Pasal 60 ayat (1) Undang-Undang Nomor 40 Tahun 2007 Tentang Perseroan Terbatas, saham merupakan benda bergerak dan memberikan hak kepada pemiliknya. Section 182 The Company Act 1985 menentukan pengertian saham, yaitu: "kekayaan personal dan dapat dialihkan sesuai dengan ketentuan anggaran dasar."

Penggunaan saham terdapat dalam Pasal 51 ayat (1) UU PT, yaitu: a). menghadiri dan mengeluarkan suara dalam RUPS; b). menerima pembayaran dividen dan sisa kekayaan hasil likuidasi; c). menjalankan hak lainnya berdasarkan undang-undang ini.

Dalam Pasal 53 ayat (3) dan ayat (4) UU PT telah ditentukan klasifikasi saham biasa, yaitu: a). Saham dengan hak suara atau tanpa hak suara; b). Saham dengan hak khusus untuk mencalonkan anggota direksi dan/atau anggota dewan komisaris; c). Saham yang setelah jangka waktu tertentu ditarik kembali atau ditukar dengan klasifikasi saham lain; d). Saham yang memberikan hak kepada pemegangnya untuk menerima dividen lebih dahulu dari pemegang saham klasifikasi lain atas pembagian dividen secara kumulatif atau nonkumulatif; saham yang memberikan hak kepada pemegangnya untuk menerima lebih dahulu dari pemegang saham klasifikasi lain atas pembagian sisa kekayaan perseroan dalam likuidasi.

\section{Pengertian Perusahaan Terbuka}

Perusahaan Terbuka adalah Perusahaan Publik yang telah melakukan Penawaran Umum saham atau Efek bersifat Ekuitas lainnya. ${ }^{5}$ Sedangkan Perusahaan Publik adalah perseroan yang sahamnya telah dimiliki sekurangkurangnya oleh 300 (tiga ratus) pemegang saham dan memiliki modal disetor sekurang-kurangnya Rp. 3.000.000.000,00 (tiga milyar rupiah) atau suatu jumlah pemegang saham dan modal disetor yang ditetapkan dengan Peraturan Pemerintah. (Pasal 1 ayat 22 Undang-Undang Nomor 8 Tahun 1995 Tentang Pasar Modal).

Perusahaan Terbuka disebut juga sebagai emiten yang berdasarkan Pasal 1 ayat 6 UU Pasar Modal yaitu Pihak yang melakukan penawaran umum. ${ }^{6}$ Dalam hal ini perlu dijelaskan bahwa Emiten dan Perusahaan Publik terdapat perbedaan, yakni perusahaan publik belum tentu emiten, karena perusahaan publik belum tentu melakukan penawaran umum atau listing di bursa. Sedangkan emiten sudah pasti perusahaan publik, karena telah

\footnotetext{
${ }^{4}$ Salim, Hukum Divestasi di Indonesia, (Mataram: Penerbit Erlangga), 2010, h. 42.

${ }^{5}$ Pasal 1a Keputusan Ketua Bapepam-LK No. Kep-259/BL/2008 tentang Peraturan No. IX.H.1 tentang Pengambilalihan Perusahaan Terbuka, ditetapkan tanggal 30-06-2008.

${ }^{6}$ Penawaran umum menurut Pasal 1 ayat 15 UU Pasar Modal adalah kegiatan penawaran Efek yang dilakukan oleh Emiten untuk menjual Efek kepada masyarakat berdasarkan tata cara yang diatur dalam Undang-Undang Pasar Modal dan peraturan pelaksananya.
} 
memenuhi persyaratan sebagai perusahaan publik dilihat dari jumlah pemegang saham dan modal minimal yang harus disetor. Emiten melakukan penawaran umum dan sahamnya aktif diperdagangkan di bursa (secondary market). ${ }^{7}$

Emiten atau perusahaan publik adalah pihak yang melakukan penawaran umum dalam rangka menjaring dana bagi kegiatan usaha perusahaan atau pengembangan usaha perusahaan.

\section{Proses Perusahaan Terbuka di Pasar Modal}

Hal pertama yang dilakukan Emiten atau Perusahaan Terbuka Pasar Modal sebelum listing di Bursa Saham adalah melakukan penawaran umum. UU Pasar Modal Nomor 8 Tahun 1995 mengatakan bahwa penawaran umum (public offering) yaitu kegiatan efek yang dilakukan oleh emiten untuk menjual efek kepada masyarakat berdasarkan tata cara yang diatur dalam undang-undang ini dan peraturan pelaksanaan.

Penawaran Umum sering pula dikenal dengan istilah go public. Dengan go public perusahaan mendapatkan dana sesuai dengan kebutuhan perusahaan tersebut. Ketika menjalani penawaran umum, perusahaan dibantu oleh beberapa pihak ${ }^{8}$ yaitu lembaga penunjang (Kustodian, Badan Administrasi Efek, dan Penanggung) dan profesi penunjang (Akuntan, Konsultasi Hukum, Notaris, dan Penilai), sehingga penawaran tersebut berlangsung lancar dan memenuhi ketentuan yang ada.

\section{Pengertian Kepailitan}

Ketentuan umum dalam Pasal 1 angka 1 Undang-Undang Nomor 37 Tahun 2004 tentang Kepailitan dan Penundaan Kewajiban Pembayaran Utang memberikan definisi mengenai Kepailitan yaitu: sita umum atas semua kekayaan Debitor Pailit yang pengurusan dan pemberesannya dilakukan oleh Kurator di bawah pengawasan Hakim Pengawas sebagaimana diatur dalam Undang-Undang ini. Dari definisi di atas, dapat ditarik kesimpulan bahwa unsur-unsur kepailitan adalah: ${ }^{9}$

Pertama; Sita umum, adalah penyitaan atau pemberesan terhadap seluruh harta Debitor pailit. Pengertian sita umum ini membedakan dengan sita khusus seperti revindicatoir beslag, konservatoir beslag, dan eksekutor beslag yang semuanya merupakan beslag atau sita khusus terhadap bendabenda tertentu. Meskipun kepailitan tersebut dikatakan sebagai sita umum, sebagaimana Pasal 21 Undang-Undang Kepailitan dan Penundaan Kewajiban Pembayaran Utang, "Kepailitan meliputi seluruh kekayaan Debitor pada saat putusan pernyataan pailit diucapkan serta sesuatu yang diperoleh selama kepailitan”.

\footnotetext{
${ }^{7}$ Nasaruddin, Irsan, Aspek Hukum Pasar Modal, (Jakarta: Kencana)2010, cet. ke-6, h.155.

${ }_{9}^{8}$ Irsan Nasaruddin, Aspek Hukum Pasar Modal, h.113.

${ }^{9}$ Man S Sastrawidjaja, Hukum Kepailtian dan Penundaan Kewajiban Pembayaran Utang, (Bandung: PT Alumni), 2010, cet. ke2, h. 78-81.
} 
Kedua; Terhadap kekayaan Debitor Pailit. Hal ini menunjukkan bahwa kepailitan itu terhadap harta bukan terhadap pribadi Debitor.

Ketiga; Pengurusan dan pemberesan oleh Kurator. ${ }^{10}$ Artinya, sejak pernyataan pailit, Debitor pailit kehilangan hak untuk mengurus dan menguasai hartanya. Hal ini ditegaskan dalam Pasal 24 Undang-Undang Kepailitan dan Penundaan Kewajiban Pembayaran Utang, "Debitor demi hukum kehilangan haknya untuk menguasai dan mengurus kekayaannya yang termasuk dalam harta pailit, sejak tanggal putusan pernyataan pailit diucapkan.”

Dengan dinyatakan pailit, Debitor kehilangan haknya atau kehilangan kewenangannya (onbevoegd) untuk mengurus dan menguasai hartanya merupakan salah satu asas umum kepailitan. Dengan demikian, Debitor Pailit dianggap tidak cakap (onbekwaan) untuk mengurus dan menguasai hartanya tersebut. Pengurusan dan penguasaan atas harta kekayaan Debitor beralih kepada Kurator.

Keempat; Terdapat Hakim Pengawas. ${ }^{11}$ Tugas utama Hakim Pengawas dalam kepailitan Debitor yang bersangkutan adalah melakukan pengawasan atas pengurusan dan penguasaan harta Debitor pailit oleh Kurator. ${ }^{12}$

\section{Syarat Kepailitan}

Syarat kepailitan diatur oleh Pasal 2 Undang-Undang Kepailitan dan PKPU menyimpulkan bahwa syarat-syarat yuridis agar suatu perusahaan dapat dinyatakan pailit adalah sebagai berikut; ${ }^{13}$ adanya utang, ${ }^{14}$ minimal satu dari utang sudah jatuh tempo, minimal satu dari utang yang dapat ditagih, adanya debitor, adanya kreditor, kreditor lebih dari satu, ${ }^{15}$ pernyataan pailit

${ }^{10}$ Menurut Pasal 1 butir 5 Undang-Undang Nomor 37 Tahun 2004 Tentang Kepailitan dan PKPU bahwa Kurator adalah Balai Harta Peninggalan atau orang perseorangan yang diangkat oleh Pengadilan untuk mengurus dan membereskan harta Debitor Pailit di bawah pengawasan Hakim Pengawas sesuai dengan Undang-Undang ini.

${ }^{19}$ Pasal 1 butir 8 Undang-Undang Nomor 37 Tahun 2004 Tentang Kepailitan dan Penundaaan Kewajiban Pembayaran Utang mendefinisikan Hakim Pengawas yaitu hakim yang ditunjuk Pengadilan dalam putusan pailit atau putusan penundaan kewajiban pembayaran utang.

12 Pengaturan mengenai hal-hal yang berkaitan dengan Hakim Pengawas berada dalam Pasal 65-68 Undang-Undang Nomor 37 Tahun 2004 Tentang Kepailitan dan PKPU.

${ }^{13}$ Munir Fuady, Hukum Kepailitan dalam Teori dan Praktek, (Jakarta: Citra Aditya Bakti), 2010, cet. ke-4, h. 8-9.

${ }_{14}$ Pasal 1 butir 6 Undang-Undang Kepailtian dan PKPU memberikan pengertian utang, yaitu kewjiban yang dinyatakan atau dapat dinyatakan dalam jumlah uang, baik dalam mata ung Indonesia maupun mata uang asing, baik secara langsung maupun akan timbul di kemudian hari atau kontinjen, yang timbul karena perjanjian atau undang-undang dan yang wajib dipenuhi oleh debitor dan bila tidak dipenuhi memberi hak kepada kreditor untuk mendapat pemenuhannya dari harta kekayaan debitor.

${ }_{5}$ Menurut Jono, secara umum ada 3 (tiga) macam kreditor yang dikenal dalam KUH Perdata, yaitu: a). Kreditur konkuren, yang diatur dalam Pasal 1132 KUH Perdata, yaitu para kreditor dengan hak pari passu dan pro rata, artinya para kreditor secara bersama-sama memperoleh pelunasan (tanpa ada yang didahulukan) yang dihitung berdasarkan pada besarnya piutang masing-masing dibandingkan terhadap piutang mereka secara keseluruhan, terhadap 
dilakukan oleh pengadilan khusus yang disebut dengan "Pengadilan Niaga". Permohonan pernyataan pailit diajukan oleh pihak yang berwenang, yaitu; pihak debitor; Satu atau lebih kreditor; Jaksa untuk kepentingan umum; Bank Indonesia jika debitornya bank; Bapepam jika debitornya perusahan efek, bursa efek, lembaga kliring dan penjaminan, dan lembaga penyimpanan dan penyelesaian; serta Menteri Keuangan jika debitornya perusahaan asuransi, reasuransi, dana pensiun, dan BUMN yang bergerak di bidang kepentingan publik. Syarat-syarat yuridis lainnya yang disebutkan dalam Undang-Undang Kepailitan. Apabila syarat-syarat terpenuhi, hakim "menyatakan pailit", bukan "dapat menyatakan pailit".

\section{Pihak-Pihak yang Dapat Mengajukan Kepailitan}

Menurut Lilik Muljadi pihak yang dapat mengajukan kepailitan atau pihak pemohon pailit adalah pihak yang mengajukan dan memohon kepada Pengadilan Niaga yang berwenang agar Debitor dinyatakan pailit dengan segala akibat hukumnya, kemudian ditunjuk Kurator dan Hakim Pengawas terhadap harta kekayaan Debitor Pailit. ${ }^{16}$

Sesuai dengan Pasal 2 Undang-Undang Nomor 37 Tahun 2004 Tentang Kepailitan dan PKPU, pihak yang dapat mengajukan permohonan pailit adalah:

Pertama; Debitur Sendiri (Pasal 2 ayat (1) UU Kepailitan dan PKPU). "Debitor yang mempunyai dua atau lebih Kreditor dan tidak membayar lunas sedikitnya satu utang yang telah jatuh waktu dan dapat ditagih, dinyatakan pailit dengan putusan Pengadilan, baik atas permohonannya sendiri maupun atas permohonan satu atau lebih kreditornya."

Kedua; Seorang Kreditor atau Lebih (Pasal 2 ayat (1) UU Kepailitan dan PKPU). Penjelasan Pasal 2 ayat (1) UU Kepailitan dan PKPU menjelaskan mengenai kreditor yang dapat mengajukan permohonan pailit terhadap debitornya, yaitu kreditor konkuren, kreditor preferen, ataupun kreditor separatis.

Ketiga; Kejaksaan (Pasal 2 ayat (2) UU Kepailitan dan PKPU). "Permohonan sebagaimana dimaksud pada ayat (1) dapat juga diajukan oleh kejaksaan untuk kepentingan umum."

\section{PKPU)}

Keempat; Bank Indonesia (Pasal 2 ayat (3) UU Kepailitan dan

"Dalam hal Debitor adalah bank, permohonan pernyataan pailit hanya dapat diajukan oleh Bank Indonesia."

seluruh harta kekayaan debitor tersebut. b). Kreditor preferen (yang diistimewakan), yaitu kreditor yang oleh undang-undang, semata-mata karena sifat piutangnya, mendapatkan pelunasan terlebih dahulu. Kreditur separatis, yaitu kreditur pemegang hak jaminan kebendaan in rem, yang dalam KUH Perdata disebut dengan nama gadai dan hipotek. (Jono, Hukum Kepailitan, Jakarta: Sinar Grafika. 2010), cet. ke-2, h. 5.

${ }^{16}$ Lilik Mulyadi, Perkara Kepailitan dan Penundaan Kewajiban Pembayaran Utang, (Bandung: PT Alumni, 2010), cet. ke-1, h. 127. 
Kelima; Badan Pengawas Pasar Modal (Pasal 2 ayat (4) UU Kepailitan dan PKPU). "Dalam hal Debitor adalah Perusahaan Efek, Bursa Efek, Lembaga Kliring dan Penjaminan, Lembaga Penyimpanan dan Penyelesaian, permohonan pernyataan pailit hanya dapat diajukan oleh Badan Pengawas Pasar Modal."

Keenam; Menteri Keuangan (Pasal 2 ayat (4) UU Kepailitan dan PKPU). "Dalam hal Debitor adalah Perusahaan Asuransi, Perusahaan Reasuransi, Dana Pensiun, atau Badan Usaha Milik Negara yang bergerak di bidang kepentingan publik, permohonan pernyataan pailit hanya dapat diajukan oleh Menteri Keuangan.”

\section{Akibat Hukum Debitor yang Dipailitkan}

Ada beberapa akibat hukum terhadap debitor yang dipailitkan, diantaranya yaitu:

Pertama, terhadap Kekayaan Debitor. Pasal 1131 Kitab UndangUndang Hukum Perdata mengatakan bahwa semua aset debitur, baik yang sudah ada pada saat ini dan di kemudian hari menjadi tanggungan untuk utang debitur.

Pasal 21 Undang-Undang Nomor 37 Tahun 2004 tentang Kepailtian dan Penundaan Kewajiban Pembayaran Utang menegaskan tentang akibat hukum Debitor yang dipailitkan, "Kepailitan meliputi seluruh kekayaan Debitor pada saat putusan pernyataan pailit diucapkan serta segala sesuatu yang diperoleh selama kepailitan.”

Sejak putusan pailit diucapkan, pengurusan harta pailit dilakukan oleh Kurator di bawah pengawasan Hakim Pengawas. Menurut Lilik Mulyadi, ${ }^{17}$ dalam praktiknya tidak seluruh harta Debitor di bawah pengurusan Kurator dan dapat tetap di bawah penguasaan Debitor Pailit. Harta kekayaan Debitor tersebut yang tetap dapat di bawah penguasaan Debitor Pailit ditetapkan dalam Pasal 22 UU Kepailitan dan PKPU.

Hak untuk mengurus dan membereskan harta Debitor beralih kepada Kurator di bawah pengawasan Hakim Pengawas, meskipun terhadap putusan permohonan pernyataan pailit tersebut diajukan upaya hukum kasasi atau PK. Meskipun debitor kehilangan hak untuk mengurus dan menguasai harta kekayaannya tetapi debitor tidak kehilangan kecakapan untuk melakukan perbuatan hukum tersebut sepanjang perbuatan hukum tersebut tidak mempunyai akibat hukum atas harta kekayaannya yang telah dikuasai kurator.

Kedua, terhadap Perikatan-Perikatan. Seperti; perjanjian timbal balik, penyerahan barang, perjanjian sewa menyewa, dan hubungan kerja.

a). Perjanjian Timbal Balik. Prof. Subekti menerjemahkan istilah oevereenkomst dari Bahasa Belanda ke dalam bahasa Indonesia, yaitu "Perjanjian". Pasal 1313 KUH Perdata memberikan definisi perjanjian, yaitu

\footnotetext{
${ }^{17}$ Lilik Mulyadi, Perkara Kepailitan dan Penundaan Kewajiban Pembayaran Utang,
} 
suatu perbuatan dengan mana satu orang atau lebih mengikatkan dirinya terhadap satu orang lan atau lebih..$^{18}$

Pasal 36 ayat (1) UU Kepailitan dan PKPU menentukan bahwa dalam hal putusan pernyataan pailit diucapkan, terdapat perjanjian timbal balik yang belum atau baru sebagian dipenuhi, pihak yang mengadakan perjanjian dengan debitur dapat meminta kepada kurator untuk memberikan kepastian tentang kelanjutan pelaksanaan perjanjian tersebut. Dalam hal kesepakatan mengenai jangka waktu yang tersebut tidak tercapai, hakim pengawas menetapkan jangka waktu tersebut (Pasal 36 ayat (2) UU Kepailitan dan PKKPU). Apabila dalam jangka waktu tersebut kurator tidak memberikan jawaban atau tidak bersedia melanjutkan pelaksanaan perjanjian tersebut, maka dapat dituntut ganti rugi dan akan diperlakukan sebagai kreditur konkuren (Pasal 36 ayat (3) UU Kepailitan dan PKPU). Apabila kurator menyatakan kesanggupannya atas pelaksanaan perjanjian tersebut, kurator wajib memberi jaminan atas kesanggupan untuk melaksanakan perjanjian tersebut. Pelaksanaan perjanjian tersebut tidak meliputi perjanjian yang prestasinya harus dilaksanakan sendiri oleh debitur, misalnya debitur adalah seorang penyanyi atau pelukis, di mana debitur diwajibkan melukis wajah pihak tersebut. Dalam hal tersebut tidak mungkin bagi kurator untuk melaksanakan perjanjian. ${ }^{19}$

b). Penyerahan Barang. Apabila diperjanjikan penyerahan benda dagangan dengan suatu jangka waktu dan pihak yang harus menyerahkan benda tersebut sebelum penyerahan dilaksanakan dinyatakan pailit, maka perjanjian menjadi hapus dengan diucapkannya Putusan Pernyataan Pailit. Dalam hal pihak lawan dirugikan, maka yang bersangkutan dapat mengajukan diri sebagai kreditor konkuren untuk mendapatkan ganti rugi. Bila harta pailit dirugikan karena penghapusan, maka pihak lawan wajib membayar ganti kerugian (Pasal 37 UU Kepailitan dan PKPU).

c). Perjanjian Sewa Menyewa. Bila Debitor telah menyewa suatu benda, maka baik Kurator maupun pihak yang menyewakan benda dapat menghentikan perjanjian sewa dengan syarat pemberitahuan penghentian dilakukan sebelum berakhirnya perjanjian sesuai dengan adat kebiasaan setempat. Untuk itu harus diindahkan pemberitahuan penghentian menurut perjanjian atau menurut kelaziman dalam jangka waktu paling singkat 90 (sembilan puluh) hari. Bila uang telah dibayar di muka, maka perjanjian sewa tidak dapat dihentikan lebih awal sebelum berakhirnya jangka waktu yang telah dibayar uang sewa tersebut. Sejak tanggal Putusan pernyataan pailit diucapkan. Uang sewa merupakan utang harta pailit (Pasal 38 UU Kepailitan dan PKPU).

d). Hubungan Kerja. Pekerja yang bekerja pada Debitor dapat memutuskan hubungan kerja dan sebaliknya Kurator dapat memberhentikannya dengan mengindahkan jangka waktu menurut

${ }^{18}$ Kitab Undang-Undang Hukum Perdata (Burgelijk Wetboek), diterjemahkan oleh R. Subekti dan R. Tjitrosudibio, cet. ke-33, (Jakarta: Pradnya Paramita, 2003), Pasal 1313.

${ }^{19}$ Jono, Hukum Kepailitan, h.112. 
persetujuan atau ketentuan perundang-undangan yang berlaku. Dengan pengertian paling singkat 45 (empat puluh lima) hari sebelumnya, sejak tanggal Putuan pernyataan pailit diucapkan. Upah ${ }^{20}$ yang terutang sebelum maupun sesudah pernyataan pailit diucapkan merupakan utang harta pailit (Pasal 39 UU Kepailitan dan PKPU).

Ketiga, terhadap Harta Warisan. Warisan yang selama kepailitan jatuh kepada Debitor pailit oleh kurator tidak boleh diterima, kecuali apabila menguntungkan harta pailit. Untuk itu, kurator memerlukan izin dari Hakim Pengawas (Pasal 40 UU Kepailitan dan PKPU).

Keempat, Pembayaran Utang. Jika sebelum Putusan Pailit dijatuhkan Debitor telah melakukan pembayaran utangnya kepada Kreditor tertentu, maka pembayaran utang tersebut dapat dibatalkan apabila: 1). Dapat dibuktikan bahwa penerima pembayaran mengetahui bahwa permohonan pernyataan pailit debitor sudah didaftarkan, 2). Pembayaran tersebut merupakan persekongkolah antara Debitor dan Kreditor dengan maksud untuk menguntungkan bagi Kreditor tersebut melebihi kreditor-kreditor lainnya (Pasal 45 UU Kepailitan dan PKPU).

Kelima, Actio Paulina dalam Proses Kepailitan. Merujuk kepada Pasal 1341 KUHPerdata bahwa berlakunya actio paulina terhadap perbuatan hukum si pailit yang dilakukan sebelum putusan pailit, artinya kreditor boleh mengajukan tidak berlakunya segala tindakan yang tidak diwajibkan yang dilakukan oleh debitor, dengan nama apa pun juga yang merugikan kreditor; asal dibuktikan bahwa ketika tindakan itu dilakukan, debitor dan orang yang dengannya atau untuknya debitor itu bertindak.

Suatu perusahaan terdapat dua kelompok pemegang saham, yaitu pemegang saham mayoritas dan pemegang saham minoritas. Pemegang saham mayoritas pada prinsipnya memiliki jaminan perlindungan hukum, terutama melalui mekanisme Rapat Umum Pemegang Saham, yang jika tidak dapat diambil secara musyawarah, maka akan diambil dengan keputusan yang diterima oleh mayoritas. Jika suara yang diambil dari pemegang saham mayoritas, bagaimana kedudukan pemegang saham minoritas. Padahal suara minoritas juga mesti mendapat perlindungan, meskipun tidak harus sampai menjadi pihak yang mengatur perusahaan. ${ }^{21}$ Prinsip majority rule minority protection merupakan prinsip yang memberikan kewenangan untuk mengatur perusahaan pada pemegang saham mayoritas dalam hal ini lewat mekanisme Rapat Umum Pemegang Saham.

Peraturan perundang-undangan di Indonesia belum ada yang mendefinisikan pengertian pemegang saham minoritas dalam ketentuan

${ }^{20}$ Menurut UU No. 13 Tahun 2003 Tentang Ketenagakerjaan bahwa upah adalah hak pekerja/buruh yang diterima dan dinyatakan dalam bentuk uang sebagai imbalan dari pengusaha atau pemberi kerja kepada pekerja/buruh yang ditetapkan dan dibayarkan menurut suatu perjanjian kerja, kesepakatan, atau peraturan perundang-undangan, termasuk tunjangan bagi pekerja/buruh dan keluarganya atas suatu pekerjaan dan/atau jasa yang telah atau akan dilakukan.

${ }^{21}$ Munir Fuady, Perlindungan Pemegang Saham Minoritas, (Bandung: CV Utomo, 2005), cet. ke-1, h. 1 
umum, ${ }^{22}$ namun dalam ketentuan atau pasal lainnya dalam suatu perundangundangan memberikan beberapa perlindungan terhadap pemegang saham minoritas. Pemegang saham minoritas perlu dilindungi mengingat adanya prinsip keadilan dalam suatu perseroan. Pemberlakuan prinsip keadilan mengharuskan diberikannya kekuasaan tertinggi kepada rapat umum pemegang saham, di mana suara terbanyak yang akan menentukan putusannya. Hal ini mengakibatkan perlunya penjaminan hak terhadap pemegang saham minoritas. ${ }^{23}$

Undang-Undang Nomor 40 Tahun 2007 Tentang Perseroan Terbatas memberikan beberapa perlindungan terhadap pemegang saham minoritas. UU Perseroan Terbatas menjamin adanya prinsip one share one vote dalam Pasal 84 ayat (1) yang menyatakan bahwa "Setiap saham yang dikeluarkan mempunyai satu hak suara kecuali anggaran dasar menentukan lain”, pemegang saham minoritas berhak memberikan suaranya dalam rapat umum pemegang saham. Kemudian Pasal 87 ayat (1) dan ayat (2) menyatakan bahwa; "(1) Keputusan RUPS diambil berdasasrkan musyawarah untuk mufakat; (2) dalam hal keputusan berdasarkan musyawarah untuk mufakat sebagaimana dimaksud dalam ayat (1) tidak tercapai, keputusan adalah sah jika disetujui lebih dari $1 / 2$ (satu perdua) bagian dari jumlah suara yang dikeluarkan kecuali undang-undang dan/atau anggaran dasar menentukan bahwa keputusan adalah sah jika disetujui oleh jumlah suara setuju yang lebih besar."

\footnotetext{
${ }^{22}$ National Legal Reform dalam Ikhtisar Ketentuan Pasar Modal memberikan beberapa definisi terhadap pemegang saham, diantaranya: a. Pemegang saham independen yaitu pemegang saham yang tidak mempunya Benturan Kepentingan sehubungan dengan suatu Transaksi tertentu dan/atau bukan merupakan Afiliasi dari anggota Direksi, anggota Dewan Komisaris atau pemegang saham utama yang mempunyai Benturan Kepentingan atau Transaksi tertentu (Keputusan Ketua Bapepam-LK No. Kep. 412/BL/2009 tentang Transaksi Afiliasi dan Benturan Kepentingan Transaksi Tertentu, ditetapkan tanggal 25-11-2009). b. Pemegang Saham Pengendali yaitu Pemegang saham yang memiliki 25\% (dua puluh lima perseratus) atau lebih saham perusahaan, atau pemegang saham yang memiliki kemampuan dengan cara apapun mempengaruhi pengelolaan dan atau kebijaksanaan perusahaan meskipun jumlah saham yang dimiliki kurang dari 25\% (dua pulun lima perseratus) (Keputusan Direksi PT Bursa Efek Jakarta No. Kep. 305/BEJ/2004 tentang Peraturan No. 1-A tentang Pencatatan Saham dan Efek bersifat Ekuitas Selain Saham yang Diterbitkan Oleh Perusahaan Tercatat, ditetapkan tanggal 19-7-2004, Pasal 1.15). c. Pemegang Saham Pengendali yaitu pemegang saham dari perusahaan Sponsor yang memiliki saham lebih dari 50\% (lima puluh perseratus) dari seluruh saham yang disetor penuh, atau Pihak yang mempunyai kemampuan untuk menentukan, baik langsung maupun tidak langsung, dengan cara apapun pengelolaan dan atau kebijaksanaan Perusahaan Sponsor (Keputusan Direksi PT Bursa Efek Indonesia No. Kep00389/BEI/06-2009 tentang Konsep Peraturan No.1-D tentang Pencatatan Sertifikat Penitipan Efek Indonesia (SPEI) di Bursa, ditetapkan tanggal 12-062009, Pasal1.14). d. Pemegang Saham Utama yaitu pihak yang baik secara langsung maupun tidak langsung, memiliki sekurang-kurangnya $20 \%$ (dua puluh perseratus) hak suara dari seluruh saham yang mempunyai hak suara yang dikeluarkan oleh suatu Perseroan atau jumlah yang lebih kecil dari itu sebagaimana ditetapkan oleh BAPEPAM (Keputusan Badan Arbitrase Pasar Modal Indonesia No. Kep-05/BAPMI/12.2002, ditetapkan tanggal 20-12-2002, Pasal6).

${ }^{23}$ Munir Fuady, Perlindungan Pemegang Saham Minoritas, h. 19.
} 
Berdasarkan prinsip keadilan bahwa putusan oleh mayoritas dalam suatu RUPS tidak selamanya fair bagi pemegang saham minoritas, meskipun cara pengambilan putusan secara mayoritas tersebut dianggap yang paling demokratis. Pemberlakuan teori demokrasi dalam suatu perseroan terbatas terjelma dalam sistem pengambilan keputusan oleh rapat umum pemegang saham. Di samping itu, komposisi dari organ perusahaan juga menunjukan adanya pilar-pilar demokrasi dalam suatu perseroan terbatas.

Pilar-pilar demokrasi ditunjukan oleh pengaturan tentang komposisi dari organ perusahaan dalam suatu perseroan terbatas. Sebagaimana diketahui bahwa dalam suatu perseroan terbatas, terdapat organ perseroan sebagai berikut:

Pertama, Rapat Umum Pemegang Saham, yaitu Organ Perseroan yang mempunyai wewenang yang tidak diberikan kepada Direksi atau Dewan Komisaris dalam batas yang ditentukan oleh Undang-Undang No. 40 Tahun 2007 tentang Perseroan Terbatas dan/atau anggaran dasar. (UU No. 40 Tahun 2007 Tentang Perseroan Terbatas, Pasal 1 ayat 4).

Kedua, komisaris, yaitu organ yang bertugas melakukan pengawasan secara umum dan/atau sesuai dengan anggaran dasar serta memberi nasihat kepada Direksi. (UU` No. 40 Tahun 2007 Tentang Perseroan Terbatas, Pasal 1 ayat 6$)$.

Ketiga, direksi, yaitu Organ Perseroan yang berwenang dan bertanggung jawab atas pengurusan Perseroan untuk kepentingan Perseroan, sesuai dengan maksud dan tujuan Perseroan serta mewakili Perseroan, baik di dalam maupun di luar pengadilan sesuai dengan anggaran dasar. (UU No. 40 Tahun 2007 tentang Perseroan Terbatas, Pasal 1 ayat 5).

Dalam suatu perusahaan mengenal prinsip equal protection yang dimiliki oleh pemegang saham, baik pemegang saham mayoritas maupun pemegang saham minoritas. Undang-Undang Perseroan Terbatas menyatakan suatu prinsip umum dalam Pasal 53 ayat (2) UUPT yang menyatakan bahwa "Setiap saham dalam klasifikasi yang sama memberikan kepada pemegangnya hak yang sama."

Persamaan hak di antara pemegang saham merupakan salah satu hak dari pemegang saham, hak-hak tersebut adalah: ${ }^{24}$

Pertama, hak atas managemen dan pengontrolan perusahaan, antara lain terdiri dari: a). Hak atas voting untuk memilih dan memberhentikan direksi dan komisaris. b). Hak voting untuk melakukan perubahan fundamental terhadap perusahaan. c). Hak voting untuk merubah anggaran dasar dalam hal pengaturan tentang direksi, komisaris, RUPS, daln lain-lain. d). Hak untuk meminta agar perusahaan dikelola dengan baik untuk kepentingan perusahaan yang berarti juga untuk kepentingan seluruh pemegang saham.

Kedua, hak atas kepemilikan perusahaan, antara lain terdiri dari: a). Hak atas pembagian dividen. b). Hak atas pembagian aset pada waktu peusahaan dilikuidasi. c). Hak atas perlakuan yang sama oleh manajemen dan

\footnotetext{
${ }^{24}$ Munir Fuady, Perlindungan Pemegang Saham Minoritas, h. 173-174.
} 
pemegang saham mayoritas terhadap transaksi-transaksi penting, seperti penerbitan saham baru, perubahan anggaran dasar, dan lain-lain. d). Hak untuk didaftarkan sebagai pemegang saham alam buku register perusahaan. e). Hak untuk mendapatkan kekebalan (previllege of immunity) dari tanggung jawab pribadi atas tanggung jawab terhadap utang-utang perusahaan.

Ketiga, hak remedial dan hak-hak tambahan lainnya, antara lain terdiri dari: a). Hak atas informasi dan pemeriksaan perusahaan. b). Hak untuk menggugat derivatif (atas nama perusahaan) untuk menyelamatkan perusahaan atau mencegah kerugian atas perusahaan. c). Hak untuk membawa gugatan dan meminta ganti rugi atas pelanggaran hak individu.

Hak voting suara pemegang saham pun tergantung pada pemegang saham minoritas. Hal ini menunjukkan bahwa prinsip one share one vote diterapkan dalam setiap perusahaan terlebih adanya perbedaan ketat antara pemegang saham minoritas dengan pemegang saham mayoritas.

Ketentuan Pasal 53 ayat (2) UUPT No. 40 Tahun 2007 hanya mensyaratkan perlakuan sama antar sesama pemegang saham dalam kelas yang sama dalam arti antar pemegang saham dalam kelas yang sama tersebut tidak boleh dilakukan diskriminasi, tetapi belum dapat menyentuh unsur fairness antar pemegang saham jika: a). Pemegang sahamnya tidak dalam klasfikasi yang sama, b). Tidak terlalu sulit bagi pemegang saham mayoritas untuk mengisukan saham dalam kelas yang berbeda, c). Pemegang saham yang satu adalah minoritas sedangkan yang lainnya adalah mayoritas.

Pada dasarnya, pemegang saham minoritas memiliki hak yang sama dengan pemegang saham mayoritas. Karena para pemegang saham sekecil apapun sahamnya tetap menjadi anggota Rapat Umum Pemegang Saham (RUPS). Jadi, hak-hak RUPS menjadi hak pemegang saham minoritas, seperti berhak memperoleh segala keterangan yang berkaitan dengan kepentingan perseroan dari Direksi dan Komisaris. ${ }^{25}$

Dalam hal perusahaan mengalami kepailitan, dan pemberesan harta perusahaan dipegang oleh kurator, maka pemegang saham minoritas berhak atas:

Pertama, mengajukan keberatan atas tindakan kurator dan hakim pengawas sesuai prosedur dalam hukum pailit. Dalam hal ini, pihak pemegang saham minoritas paling jauh hanya dapat mengajukan keberatan saja. Mestinya, pihak pemegang saham minoritas juga mempunyai kewenangan untuk mengusulkan pergantian kurator sebagaimana kewenangan yang dimiliki oleh pihak kurator sendiri atau kurator lainnya, juga oleh pihak kreditor, debitor dan hakim pengawas yang diatur oleh Pasal 71 Undang-Undang Nomor 37 Tahun 2004 Tentang Kepailitan dan Penundaan Kewajiban Pembayaran Utang.

Kedua, mengajukan gugatan langsung untuk dan atas nama dirinya sendiri jika ada kerugian yang terjadi atas dirinya sendiri sebagai pemegang

${ }^{25}$ I.G.Rai, Widjaja, Hukum Perusahaan, (Jakarta: Kesaint Blanc), 2002, cet. ke-2, h.

257. 
saham terhadap kurator dan hakim pengawas yang telah merugikan kepentingannya. ${ }^{26}$

Keputusan Ketua Badan Pengawas Pasar Modal Nomor Kep46/PM/1998 tentang Keterbukaan Informasi Bagi Emiten atau Perusahaan Publik yang Dimohonkan Pailit menegaskan beberapa aturan mengenai Emiten yang dimohonkan Pernyataan Pailit, yaitu dalam hal jika emiten atau perusahaan publik gagal atau tidak mampu menghindari kegagalan untuk membayar kewajibannya terhadap pemberi pinjaman yang tidak terafiliasi, maka emiten atau perusahaan publik wajib menyampaikan laporan mengenai hal tersebut kepada Bapepam dan Bursa Efek dimana Efek Emiten atau Perusahaan Publik tercatat secepat mungkin, paling lambat akhir hari kerja ke-2 (kedua) sejak Emiten atau Perusahaan Publik mengalami kegagalan atau mengetahui ketidakmampuan/kegagalan tersebut. Laporan tersebut dalam angka 1 wajib memuat antara lain rincian mengenai pinjaman termasuk jumlah pokok dan bunga, jangka waktu pinjaman, nama pemberi pinjaman, penggunaan pinjaman dan alasan kegagalan atau ketidakmampuan menghindari kegagalan.

Dalam hal Emiten atau Perusahaan Publik diajukan ke Pengadilan untuk dimohonkan pernyataan pailit, maka Emiten atau Perusahaan Publik wajib menyampaikan laporan mengenai hal tersebut kepada Bapepam dan Bursa Efek dimana Efek Emiten atau Perusahaan Publik tercatat secepat mungkin, paling lambat akhir hari kerja ke-2 (kedua) sejak Emiten atau Perusahaan Publik mengetahui adanya permohonan pernyataan pailit dimaksud.

Laporan sebagaimana dimaksud dalam angka 3 wajib memuat antara lain nama pemberi pinjaman yang mengajukan pailit, ringkasan permohonan pernyataan pailit dan jumlah pinjaman lainnya. Pihak sebagaimana dimaksud dalam Pasal 85 Undang-undang Nomor 8 Tahun 1995 tentang Pasar Modal yang mengajukan permohonan pernyataan pailit kepada Pengadilan terhadap Emiten atau Perusahaan Publik wajib menyampaikan laporan kepada Bapepam dan Bursa Efek dimana Efek Emiten atau Perusahaan Publik tercatat mengenai hal tersebut secepat mungkin, paling lambat akhir hari kerja ke-2 (kedua) pengajuan permohonan pernyataan pailit.

Laporan sebagaimana dimaksud dalam peraturan ini merupakan dokumen publik yang tersedia bagi masyarakat di Pusat Referensi Pasar Modal sesuai dengan Peraturan Nomor II.A.2 tentang Prosedur Penyediaan Dokumen Bagi Masyarakat di Pusat Referensi Pasar Modal. Ketujuh, Bursa Efek wajib mengumumkan informasi sebagaimana dimaksud dalam peraturan ini di Bursa Efek pada hari yang sama dengan diterimanya informasi tersebut oleh Bursa Efek.

Ketentuan di atas bertujuan untuk menerapkan prinsip keterbukaan yang mana Emiten yang kedudukannya sangat penting di dunia perekonomian karena melibatkan banyak pihak yang terkait, terlebih investorinvestor yang berkedudukan sebagai pemegang saham minoritas. Prinsip

\footnotetext{
${ }^{26}$ Munir Fuady, Perlindungan Pemegang Saham Minoritas, h. 163-164.
} 
keterbukaan ini menjadi hal yang fundamental di dunia pasar modal karena kepercayaan masyarakat terhadap emiten tersebut sedang diuji, baik dan buruk yang sedang terjadi pada Emiten harus langsung dilaporkan dan diberitahukan kepada masyarakat.

Dalam prinsip Hukum Kepailitan dikenal dengan adanya prinsip commercial exit from financial distress ditujukan dalam kepailitan perseroan terbatas yang mana prinsip ini bertujuan untuk memenuhi rasa keadilan bagi kreditor dan debitor. Hadi Shubhan ${ }^{27}$ tidak sepakat dengan pihak yang meletakkan kepailitan sebagai alat bagi kreditor untuk melindungi kepentingannya semata-semata. Kepailitan seharusnya bukanlah alat untuk menekan debitor karena pada prinsipnya terdapat banyak aspek-aspek hukum yang juga memerhatikan kepentingan-kepentingan debitor yang pada akhirnya untuk meminimalisasi kerugian-kerugian terhadap kekayaan debitor, hal ini terlihat dengan adanya ketentuan masa tunggu (stay), ${ }^{28}$ ketentuan Penundaan Kewajiban Pembayaran Utang (PKPU), ketentuan rehabilitasi, dan lain sebagainya.

Ricardo Simanjuntak menyatakan bahwa kepailitan khususnya corporate insolvency sebenarnya merupakan exit from financial distress, jadi suatu jalan keluar dari persoalan yang membelit secara finansial yang mana sudah tidak bisa lagi terselesaikan. ${ }^{29}$

Pasal 142 ayat (1) UU Perseroan Terbatas menjelaskan mengenai pembubaran perseroan terjadi: ${ }^{30}$ a). Berdasarkan keputusan RUPS; b). Karena jangka waktu berdirinya yang ditetapkan dalam Anggaran Dasar telah berakhir; c). Berdasarkan penetapan pengadilan; d). Dengan dicabutnya kepailitan berdasarkan putusan pengadilan niaga yang telah mempunyai kekuatan hukum tetap, harta pailit Perseroan tidak cukup untuk membayar biaya kepailitan; e). Karena harta pailit perseroan yang telah dinyatakan pailit berada dalam keadaan insolvensi sebagaimana diatur dalam Undang-Undang tentang Kepailitan dan Penundaan Kewajiban Pembayaran Utang; f). Karena dicabutnya izin usaha Perseroan, sehingga mewajibkan Perseroan melakukan likuidasi sesuai dengan ketentuan peraturan perundang-undangan.

Dalam Perusahaan Terbuka atau emiten yang sudah melakukan Initial Public Offering atau sering disebut dengan Go Public yang memperdagangkan sahamnya di dalam sarana yang bernama Bursa Efek. Proses kepailitan emiten pasar modal, yaitu:

${ }^{27}$ Hadi Shubhan, Hukum Kepailitan (Prinsip, Norma, dan Praktik di Peradilan), (Jakarta: Kencana Prenada Media Group, 2009), cet. ke-2, h. 59.

${ }^{28}$ Hak tanggung (stay) yang diberikan debitor diatur dalam Pasal 56 ayat (2) UU Kepailitan dan PKPU yang menyatakan bahwa diberikan masa tangguh selama 90hari untuk penjualan benda jaminan yang dimiliki oleh Kreditor Separatis, dengan tenggang waktu tersebut Kurator dapat menjual benda jaminan Kreditor Separatis dengan harga yang wajar, karena menurut Hadi Shubhan dalam praktiknya Kreditor Separatis ini menjual cepat benda yang dijaminkan Kreditor dengan harga jual cepat yang mana harga jual cepat ini harga yang dibawah harga pasar. (Hadi Shubhan, Hukum Kepailitan (Prinsip, Norma, dan Praktik di Peradilan, h. 173).

\footnotetext{
${ }^{29}$ Ibid, h. 63.

${ }^{30}$ Jono, Hukum Kepailitan, h. 71.
} 
Pertama, Pengajuan Permohonan Kepailitan. Permohonan Kepailitan diajukan ke Pengadilan Niaga melalui panitera Pengadilan Niaga. Permohonan kepailitan tersebut wajib diajukan melalui advokat kecuali jika pemohonnya adalah kejaksaan, Bank Indonesia, Bapepam, atau Menteri Keuangan.

Setelah permohonan masuk ke paniteraan Pengadilan Niaga, maka pada tanggal hari itu juga panitera Pengadilan Niaga mendaftarkan permohonan tersebut dan dalam waktu paling lambat 1 x 24 jam terhitung sejak tanggal pendaftaran, panitera harus menyampaikan permohonan itu kepada Ketua Pengadilan Niaga. Selanjutnya, dalam waktu paling lambat $3 \mathrm{x}$ 24 jam sejak tanggal pendaftaran, Pengadilan Niaga harus menetapkan hari sidang dan penyelenggaraannya paling lambat 20 hari terhitung sejak tanggal permohonan didaftarkan, dan hanya atas permohonan debitor berdasarkan alasan yang cukup saja Pengadilan Niaga dapat menunda penyelenggaraan sidang paling lama 25 hari terhitung sejak tanggal permohonan pendaftaran. (Pasal 6 UU Kepailitan dan PKPU).

Setelah proses pendaftaran selesai, selanjutnya pengadilan memanggil Debitor untuk menghadiri sidang. Pengadilan wajib memanggil Debitor, dalam hal permohonan pernyataan pailit diajukan oleh kreditor, kejaksaan, Bank Indonesia, Badan Pengawas Pasar Modal, atau Menteri Keuangan. Hal ini dilakukan untuk melakukan konfrontir terhadap apa yang didalilkan oleh pihak kreditor mengenai hubungan hukumnya dan mengenai jumlah utang piutangnya. Pemanggilan selambat-lambatnya 7 hari sebelum sidang pemeriksaan pertama diselenggarakan. Adapun utusan Pengadilan Niaga selambat-lambatnya 60 hari terhitung sejak tanggal permohonan pernyataan pailit diputuskan (Pasal 8 Undang-Undang Nomor 37 Tahun 2004 Tentang Kepailitan dan Penundaan Kewajiban Pembayaran Utang).

Kedua, Proses Persidangan. Permohonan pernyataan pailit harus dikabulkan apabila terbukti secara sumir bahwa persyaratan untuk dinyatakan pailit sebagaimana yang disyaratkan dalam Pasal 1 ayat (1) UU Kepailitan dan PKPU terpenuhi, yaitu syarat adanya utang yang jatuh tempo dan adanya dua kreditor. Dalam proses persidangan kepailitan tidak dikenal adanya replik atau duplik seperti dalam hukum acara perdata, inti persidangan dalam kepailitan adalah hanya pembuktian apakah debitor mempunyai utang yang telah jatuh tempo dan mempunyai minimal dua kreditor. Namun, dalam prakteknya, sering terlihat adanya proses replik, duplik, dan yang semacamnya sehingga mirip pada hukum acara perdata biasa. ${ }^{31}$

Selama putusan atas permohonan pernyataan pailit belum ditetapkan, maka kreditor atau pemohon lainnya dapat mengajukan permohonan kepada pengadilan untuk meletakkan sita jaminan terhadap sebagian atau seluruh kekayaan debitor dan mengawasi pembayaran kepada kreditor, pengalihan, atau penjaminan kekayaan debitor yang dalam rangka kepailitan memerlukan persetujuan kurator.

31 Hadi Shubhan, Hukum Kepailitan (Prinsip, Norma, dan Praktik di Peradilan, h. 125. 
Ketiga, Delisting, adalah penghapusan pencatatan dari daftar saham di bursa yang dikarenakan tidak memenuhi ketentuan-ketentuan di bursa tersebut. Butir 5 Keputusan Ketua Badan Pengawas Pasar Modal No. Kep.56/PM/1998 tentang Keterbukaan Informasi bagi Emiten atau Perusahaan Publik yang dimohonkan Pernyataan Pailit mengatakan bahwa Emiten atau Perusahaan Publik yang gagal atau tidak mampu menghindari kegagalan untuk membayar kewajibannya terhadap pemberi pinjaman yang tidak terafiliasi, maka Emiten atau Perusahaan Publik wajib menyampaikan laporan mengenai hal tersebut kepada Bapepam dan Bursa Efek dimana Efek Emiten atau Perusahaan Publik tercatat secepat mungkin, paling lambat akhir hari kerja ke-2 (kedua) sejak Emiten atau Perusahaan Publik mengalami kegagalan atau mengetahui ketidakmampuan menghindari kegagalan dimaksud.

\section{Penutup}

Berdasarkan hasil penelitian yang penulis lakukan dan kajian-kajian tersebut dapat disimpulkan bahwa perlindungan hukum pemegang saham minoritas perusahaan terbuka akibat putusan pailit yaitu pemegang saham minoritas dapat mengajukan keberatan atas tindakan kurator sesuai prosedur dalam hukum pailit, dengan mengatasnamakan perusahaan (dalam pailit), mengajukan gugatan langsung untuk dan atas nama dirinya sendiri jika ada kerugian yang terjadi atas dirinya sendiri sebagai pemegang saham terhadap kurator yang telah merugikan kepentingannya. Sedang akibat hukum bagi perusahaan terbuka atau emiten yang mengalami pailit adalah adanya delisting atau penghapusan pencatatan dari daftar saham di bursa yang dikarenakan tidak memenuhi ketentuan-ketentuan di bursa tersebut.

\section{Pustaka Acuan}

Fuady, Munir. Hukum Kepailitan dalam Teori dan Praktek. Jakarta: Citra Aditya Bakti. 2010. cet. ke-4.

Fuady, Munir. Perlindungan Pemegang Saham Minoritas. Bandung: CV Utomo. 2005. cet. ke-1.

Jono. Hukum Kepailitan. Jakarta: Sinar Grafika. 2010. Cet. Ke-2.

Lay, Alexander, dkk. Ikhtisar Ketentuan Pasar Modal. Jakarta: The Indonesia Netherlands National Legal Reform Program. 2010.

Mulyadi, Lilik. Perkara Kepailitan dan Penundaan Kewajiban Pembayaran Utang. Bandung: PT Alumni. 2010. cet. ke-1.

Nasaruddin, Irsan. Aspek Hukum Pasar Modal. Jakarta: Kencana. 2010. cet. ke-6.

Salim. Hukum Divestasi di Indonesia. Mataram: Penerbit Erlangga. 2010.

Shubhan, Hadi. Hukum Kepailitan (Prinsip, Norma, dan Praktik di Peradilan). Jakarta: Kencana Prenada Media Group. 2009. Cet. Ke-2.

S Sastrawidjaja, Man. Hukum Kepailtian dan Penundaan Kewajiban Pembayaran Utang. Bandung: PT Alumni. 2010. cet. ke2.

Widjaja, I.G.Rai, Hukum Perusahaan. Jakarta: Kesaint Blanc. 2002. Cet. Ke2. 